\title{
Molecular genetics of the extracellular lipase of Pseudomonas aeruginosa PAO1
}

\author{
Susanne Wohlfarth, ${ }^{*}$ Christine Hoesche, $\dagger$ Corina Strunk and Ulrich K. Winkler \\ Ruhr-Universität Bochum, Lehrstuhl für Biologie der Mikroorganismen, D-4630 Bochum, FRG
}

(Received 10 December 1991; revised 27 February 1992; accepted 16 March 1992)

\begin{abstract}
The structural gene (lipA) coding for the extracellular lipase of Pseudomonas aeruginosa PAO1 has been cloned on plasmid pSW118. Nucleotide sequence analysis revealed a gene of $936 \mathrm{bp}$. lipA codes for a proenzyme of 311 amino acids including a leader sequence of 26 amino acids. The mature protein was predicted to have a $M_{\mathrm{r}}$ of 30134, an isoelectric point of 5.6, and a consensus sequence (IGHSHGG) typical of lipases. Furthermore it is highly homologous $(>60 \%)$ to other lipases from various pseudomonads. The lip $A$ gene failed to hybridize detectably with genomic DNA from other Pseudomonas species except $P$. alcaligenes, even under relaxed stringency. Located 220 bp downstream of the lip $A$ gene, is an open reading frame (ORF2, lipH) which encodes a hydrophilic protein (283 amino acids; $M_{\mathrm{r}}$ 33587) that shows some homology to the $\lim A$ gene product of $P$. cepacia. In complementation tests of lipase-defective mutants, lipH was shown to be necessary for expression of active extracellular lipase in $P$. aeruginosa PAO1.
\end{abstract}

\section{Introduction}

Lipases are triacylglycerol acylhydrolases (EC 3.1.1.3) that preferentially hydrolyse emulsified triglycerides. In organic solvents, lipases are also able to catalyse reverse reactions, e.g. the synthesis of esters, and transesterifications. The reaction mechanism postulated for the catalytic activities of a lipase involves an amino acid triad either of Ser-His-Asp (Winkler et al., 1990; Brady et al., 1990) or of Ser-His-Gln (Schrag et al., 1991). To test this hypothesis, the amino acid sequences and the threedimensional structures of further lipases have to be determined.

During the last few years, much progress has been made by investigating lipase genes from bacteria, especially from pseudomonads. Nucleotide sequences of lipase genes are already known for the following Gramnegative bacterial species: $P$. fragi IFO-3458 (Kugimiya et al., 1986), $P$. fragi IFO-12049 (Aoyama et al., 1988), $P$. cepacia (Jorgensen et al., 1991), P. fluorescens SIK W1 (Chung et al., 1991), P. glumae (Frenken et al., 1991),

\footnotetext{
* Author for correspondence.

† Present address: Ruhr-Universität Bochum, Institut für Physiologische Chemie, D-4630 Bochum, FRG.

The nucleotide sequence data reported in this paper have been submitted to GenBank and have been assigned the accession numbers $\mathrm{X} 63390$ (lipA) and X63391 (lipH).
}

Pseudomonas nov. sp. 109 (Ihara et al., 1991), Pseudomonas sp. (Cox et al., 1991), Pseudomonas sp. M-12-33 (Nakanishi et al., 1991), Pseudomonas sp. (Nishioka et al., 1991), P. aeruginosa $\mathrm{PAO}$ (this paper) and Moraxella sp. TA144 (Feller et al., 1990, 1991). Furthermore, lipase genes from two Gram-positive species have been published: Staphylococcus hyicus (Götz et al., 1985) and S. aureus (Lee \& Iandolo, 1986).

The lipase proteins of two different strains of $P$. aeruginosa have been purified to homogeneity and have been characterized biochemically. The lipases of $P$. aeruginosa PAC1R (Stuer et al., 1986; Jaeger et al., 1991, and in press) and of $P$. aeruginosa EF2 (Gilbert et al., 1991) both have an apparent $M_{\mathrm{r}}$ of 29000 and the mature proteins have the same $\mathrm{N}$-terminal sequences (STYTQTKYPIV...). The isoelectric points are $5 \cdot 8$ ( $P$. aeruginosa PAC1R) and 4.9 ( $P$. aeruginosa $\mathrm{EF} 2$ ). There is a strong association of the enzyme with lipopolysaccharides. The overall amino acid composition of the mature protein is known for the lipase of $P$. aeruginosa PAC1R. Analysis of two more lipase proteins purified from Pseudomonas sp. (Nishioka et al., 1991) and from Pseudomonas nov. sp. 109 (Ihara et al., 1991) also revealed an apparent $M_{\mathrm{r}}$ of 29000 and the same $\mathrm{N}$-terminal sequence for the mature protein as mentioned above. An isoelectric point of $5 \cdot 3$ was measured for Pseudomonas nov. sp. 109.

The structural gene for the lipase of $P$. aeruginosa PAOl has been mapped on the chromosome at about 
57 min (old map) or 39 min (map according to O'Hoy \& Krishnapillai, 1987) and it has been cloned on a $3.1 \mathrm{~kb}$ Sall fragment (Wohlfarth \& Winkler, 1988).

This paper reports the nucleotide sequence of the lipase gene $(\operatorname{lip} A)$ of $P$. aeruginosa PAO1 in order to compare the deduced amino acid sequence with those of other lipases and to identify conserved domains. In this connection, the lipase gene of $P$. aeruginosa PAO1 has been used as a DNA probe to search for homologous sequences in the chromosomal DNA of other pseudomonads. Moreover, the expression of the lipase gene has been studied. Finally we report on an open reading frame (ORF2, lipH) downstream of the structural gene of the lipase. The function of the gene product is unknown, but it seems to be involved in the formation of an enzymically active extracellular lipase.

Some of the results are included in European Patent no. 0334462 A1 (Andreoli et al., 1989).

\section{Methods}

Bacteria, plasmids and phage. The following wild-type strains of Pseudomonas aeruginosa were used: PAO1 (Holloway et al., 1979); FRD2 (D. Ohman, Berkeley, USA); ATCC 9027, ATCC 27853, Habs 02, Habs 12, DE-27, mucoid $\mathrm{CF}_{1} / \mathrm{M}_{1}, \mathrm{CF}_{2} / \mathrm{M}_{1}, \mathrm{CF}_{3} / \mathrm{M}_{1}$ (all from the stock culture collection of the institute, Bochum, FRG). P. fluorescens AFT36, $P$. maltophilia DSM 50170, $P$. putida, $P$. stutzeri AS 70 and Escherichia coli $\mathrm{K} 12$ were from the same source. $P$. alcaligenes DSM 50342, $P$. cepacia DSM 50181 and $P$. fragi DSM 3456 were purchased from Deutsche Sammlung von Mikroorganismen, Braunschweig, FRG. Besides these lipase-producing pseudomonads, two lip mutants of $P$. aeruginosa PAO1 (Wohlfarth \& Winkler, 1988) were used: 29-1 (met-9020 catA1 puuAI lipl) and 6-1 (met-9020 catA1 puuA1 lip2). E. coli

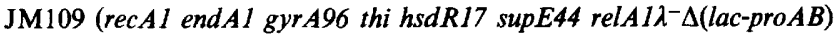
( $\mathrm{F}^{\prime}$ traD36 proAB lacI $I^{\mathrm{q}} \mathrm{Z} \triangle M 15$ ) from Yanisch-Perron et al. (1985) was utilized as a cloning host.

For cloning and sequencing experiments plasmid vectors pBluescript II SK (Stratagene), pKT248 (Bagdasarian et al., 1981), pUC19 (Yanisch-Perron et al., 1985), pUC19Ps [this study: OriV from pRC354 (Chen et al., 1987) inserted into PstI restriction site of vector pUC19] and phage M13mp19 (Yanisch-Perron et al., 1985) were used. Fig. 1 summarizes recombinant plasmids derived from pSW1 (Wohlfarth \& Winkler, 1988) and pSW112. pCH1 was constructed to clone the lipase gene of $P$. alcaligenes DSM 50342.

Media and growth conditions. Strains of Pseudomonas were grown in nutrient broth (NB; Oxoid) with aeration at $37^{\circ} \mathrm{C}$. To select for plasmids, streptomycin sulphate $\left(50 \mu \mathrm{g} \mathrm{ml}^{-1}\right)$, chloramphenicol $(20 \mu \mathrm{g}$ $\left.\mathrm{ml}^{-1}\right)$ or carbenicillin $\left(50 \mu \mathrm{g} \mathrm{ml}^{-1}\right)$ was added to the medium. E. coli was grown in Luria broth (LB) (Sambrook et al., 1989), in some cases supplemented with ampicillin $\left(50 \mu \mathrm{g} \mathrm{ml}^{-1}\right)$. IPTG (0.33 mM) and X-Gal $(0.03 \%)$ were used to detect recombinant plasmids where appropriate. The cloned lipase gene was induced in $E$. coli using $1 \mathrm{mM}$-IPTG. To grow $E$. coli for transformation, $20 \mathrm{mM}-\mathrm{Mg}^{2+}$ (equal amounts of $\mathrm{MgSO}_{4}$ and $\mathrm{MgCl}_{2}$ ) was added to the broth medium. Agar plates comprised LB or NB solidified with $1.5 \%(\mathrm{w} / \mathrm{v})$ agar. M13 phages were propagated in LB or on LB agar plates overlaid with soft agar (LB with $0.5 \%$ agar) containing IPTG and X-Gal as above. To distinguish between $\mathrm{Lip}^{+}$ and Lip- clones, a plate assay using calcium triolein (CT) agar was used (Wohlfarth \& Winkler, 1988).
Transformation and phage infection. E. coli was transformed by an altered $\mathrm{CaCl}_{2}$ method (Sambrook et al., 1989). After growing $E$. coli in the presence of $20 \mathrm{mM}-\mathrm{Mg}^{2+}$ washed cells were suspended in $40 \mathrm{mM}$ $\mathrm{MnCl}_{2}, 100 \mathrm{~mm}-\mathrm{CaCl}_{2}$ and $50 \mathrm{mM}-\mathrm{RbCl}$. For transformation of $P$. aeruginosa, early exponential growth phase cells were washed twice with $150 \mathrm{mM}-\mathrm{MgCl}_{2}$. They were held at $4{ }^{\circ} \mathrm{C}$ for $18 \mathrm{~h}$ to induce competence (Wohlfarth \& Winkler, 1988). Derivatives of phage M13 were propagated according to Sambrook et al. (1989).

DNA manipulations. Molecular genetic methods (e.g. isolation and purification of plasmid DNA and single stranded phage DNA) were done according to Sambrook et al. (1989). Chromosomal DNA was prepared by the method of Marmur (1961). Restriction enzymes and ligase were used as recommended by the suppliers (Gibco/BRL or Boehringer).

DNA sequencing and sequence analysis. Two strategies were used to obtain DNA sequences. (i) Single strand sequencing after shotgun cloning in M13mp19 of random fragments obtained by sonication (Deininger, 1983). Sequencing of these clones was performed by the dideoxy-nucleotide chain termination method of Sanger et al. (1977) using ${ }^{35}$ S-dATP (0.37 MBq, Amersham) and the Klenow fragment of DNA polymerase. To prevent sequence compressions, 7-deaza-dGTP was used instead of dGTP. Sequence data were analysed on a Cyber 855 using the program of Staden (1980). (ii) Double strand sequencing of DNA fragments obtained by restriction endonuclease cleavage or by exonuclease III/mung bean deletions (Henikoff, 1984). Alkaline- or heat-denatured plasmid DNA was directly sequenced incorporating either ${ }^{35} \mathrm{~S}$-dATP or using fluorescently labelled universal or reversed M13-primer. The T7 Deaza-Sequencing Kit or AutoRead-Sequencing Kit (both from Pharmacia) were used. Non-radioactive sequences were generated by using Pharmacia's Automated Laser Fluorescent DNA Sequencer.

Nucleotide and deduced amino acid sequences were analysed using the following programs: Staden (Amersham), DNASIS v. 5.02 and PROSIS v. 6.00 (both Hitachi Software Engineering).

Southern and colony hybridization. Transfer of DNA was performed by capillary blotting onto Gene Screen Hybridization Transfer Membrane (NEN). Bacterial colonies were lysed and denatured on Colony/Plaque Screen Membranes (NEN) as recommended by the supplier. DNA probes were labelled with ${ }^{32}$ P-dATP either by nick translation (Sambrook et al., 1989) or by using the Random Primers Labelling Kit (Gibco/BRL). Hybridization and washing conditions were as described by NEN. The Digoxigenin DNA-Labelling System (Boehringer) was used for non-radioactive Southern analysis. Stringent conditions were obtained by hybridization and washing temperature of $60-65^{\circ} \mathrm{C}$. Relaxed conditions were obtained by lowering temperature to $45^{\circ} \mathrm{C}$.

Enzyme assay. Lipase activity was measured spectrophotometrically using $p$-nitrophenyl palmitate as substrate (Wohlfarth \& Winkler, 1988).

\section{Results}

\section{Cloning the lipase gene (lipA)}

Plasmid pSW1 was previously shown to complement lipase-defective mutants $29-1$ and 6-1 of $P$. aeruginosa PAO1 (Wohlfarth \& Winkler, 1988). This plasmid carries 3 SalI fragments cloned in pKT248. It was subjected to a detailed molecular genetic analysis (Fig. 1). 


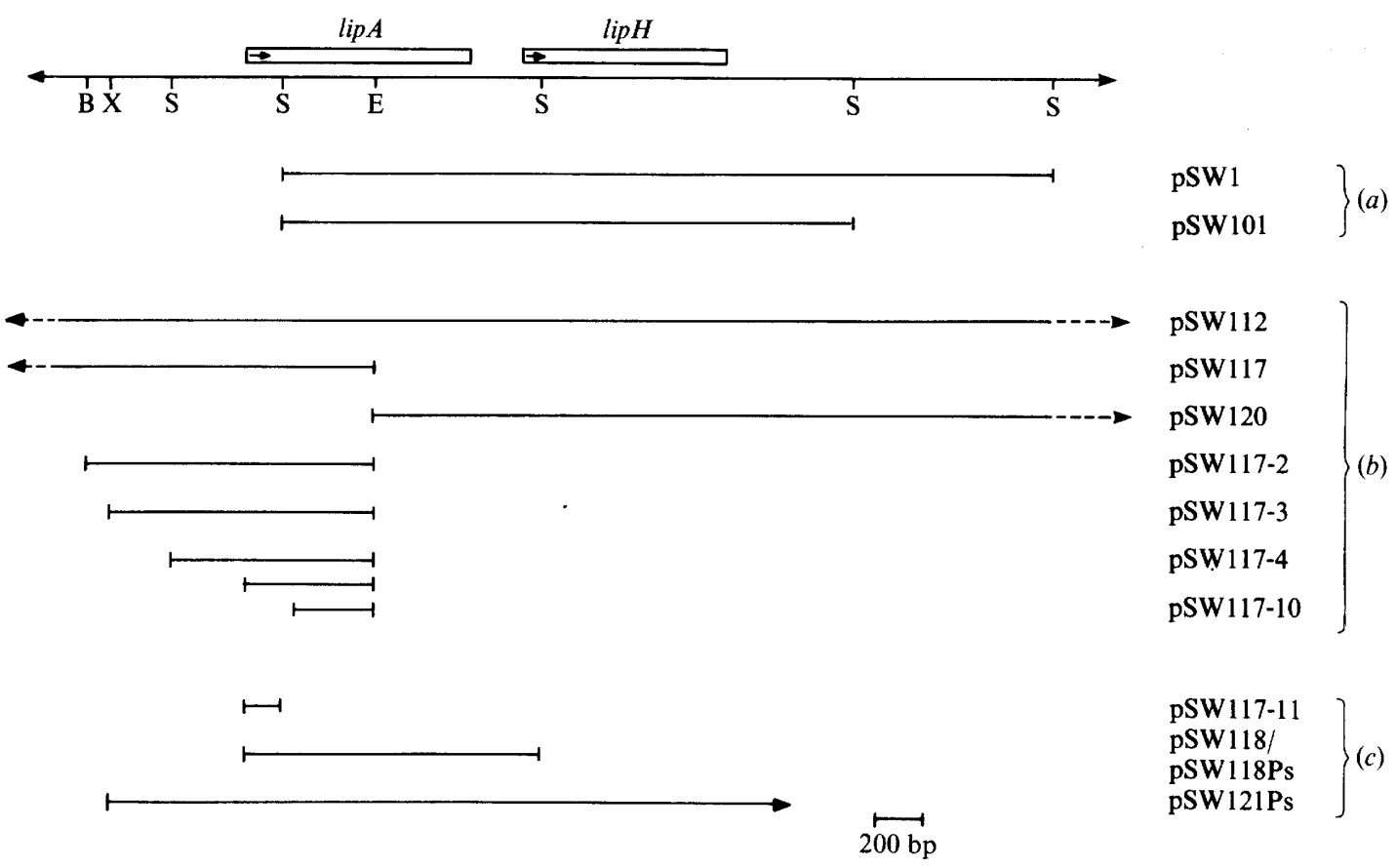

Fig. 1. Cloning and subcloning of the lipase gene from $P$. aeruginosa PAO1 and plasmid derivatives (pSW) used in this study. (a) Subcloning of pSW 1 : clones without N-terminus of the lipase gene. Vector: pK T248. (b) Cloning of the intact lipase gene using $1 \cdot 0 \mathrm{~kb}$ Sall fragment of pSW101 as a probe. Subcloning of pSW112; vector: pUC19. (c) Construction of clone pSW118 containing the intact lipase gene. Vectors: pBluescript SK II/pUC19Ps. Line drawings of inserts are to scale. Restriction sites are indicated by capital letters B: BamHI; E, EcoRI; S, SalI; X, XhoI. Genes lipA and lipH are included as boxes; arrows within indicate direction of transcription.

Two SalI fragments $(1 \cdot 0-1 \cdot 3 \mathrm{~kb})$ were inserted into the SalI restriction site within the chloramphenicol resistance gene of broad host range vector pKT248 (= pSW 101). This plasmid also fully complemented both of the lipase-defective mutants. However, neither of these fragments alone expressed complementary activity. Sequence analysis (see below) revealed that the $5^{\prime}$ part of the lipase gene was missing from clone pSW 101. The $1.0 \mathrm{~kb}$ Sall fragment, which carries $85 \%$ of the gene, was subsequently used as a probe to clone the intact gene.

Genomic DNA from $P$. aeruginosa PAO1 was digested with restriction endonuclease $P v u I I$, for which there is no cleavage site within the lip DNA in pSW101. Southern blot analysis showed a hybridizing fragment of about $20 \mathrm{~kb}$. Fragments of approximately that size $(15-25 \mathrm{~kb})$ were isolated from an agarose gel, ligated into SmaI site of pUC19 and transformed into E. coli JM109. Twenty colonies out of about 800 recombinant clones gave positive hybridization signals. One plasmid having an insert of $15.3 \mathrm{~kb}$ was named pSW112 and was further analysed. It consisted of $12 \mathrm{Sall}$ fragments, including the $1.0 \mathrm{~kb}$ and $1.3 \mathrm{~kb}$ fragments present in pSW 101 (verified by Southern hybridization, data not shown).

Restriction enzyme EcoRI, which cuts within the $1.0 \mathrm{~kb}$ Sall fragment of the lipase gene, was used for subcloning into pUC19. Two clones were selected:
pSW 120 (insert: $3.5 \mathrm{~kb}$ ) carrying the $3^{\prime}$ part and pSW 117 (insert: $4.5 \mathrm{~kb}$ ) carrying the $5^{\prime}$ part of the lipase gene, respectively. The lip DNA in pSW117 was then subcloned on a $1.2 \mathrm{~kb}$ Eco RI/BamHI fragment into pUC19 cleaved with the same enzymes. The resulting plasmid pSW117-2 was further reduced in size by subcloning an EcoRI/XhoI fragment. The ends of this fragment were made blunt before ligation into SmaI site of pUC19 to form plasmid pSW117-3. The insert of pSW117-3 was subjected to progressive exonuclease digestion (Henikoff, 1984) starting from the BamHI restriction site within the vector directly adjacent to the filled-in XhoI site of the insert. Plasmids pSW117-4 to pSW117-10 generated by this method were used for nucleotide sequencing.

Finally, a plasmid was constructed which carried the intact lipase gene lipA (Fig. 1). First, the $5^{\prime}$ part of lip $A$ was cloned into pBluescript II SK forming plasmid pSW117-11, by cutting out a $0.15 \mathrm{~kb} S a l \mathrm{I} / E c o \mathrm{RI}$ fragment of plasmid pSW117-8 (the $S a l$ site comes from the lipase gene and the $E c o$ RI site from the vector; Figs 1 and 2). The main part of the lipase gene ( $3^{\prime}$ part) came from plasmid pSW101 by ligating the $1.0 \mathrm{~kb} S a l \mathrm{I}$ fragment into the SalI site of plasmid pSW117-11, forming pSW 118. The correct orientation of the $1.0 \mathrm{~kb}$ fragment (Fig. 1) to form an intact lipase gene was 
$\begin{array}{llllllllll}1 & 10 & 20 & 30 & 40 & 50 & 60 & 70 & 80 & 90\end{array}$ GTCGACCATTTCAGCCTGTTTTGCTCGCAAAACGACGCCGCGGGCGTGCGCTACCGCACACTCCGTCGCTGGGCGTTGTGCGGGGAAGATTCAAACGAGC $\begin{array}{llllllllll}110 & 120 & 130 & 140 & 150 & 160 & 170 & 180 & 190 & 200\end{array}$ GTTTCGCGCCGTAACAACCCGCTCTCTTCCGCTCTGCCACGCAGGITATGACCGCCCGCCAGGAAGCCGCGGATTICCTGGCCTGGAGGAAAAAAGCCGA $\begin{array}{llllllllll}210 & 220 & 230 & 240 & 250 & 260 & 270 & 280 & 290 & 300\end{array}$ AGCTGGCACGGTTCCTGGCGCAAGGGACAGCGAAGCGGTTCTCCCGGAAGGATTCGGGCGATGGCTGGCAGGACGCGCCCCTCGGCCCCATCAACCTGAG

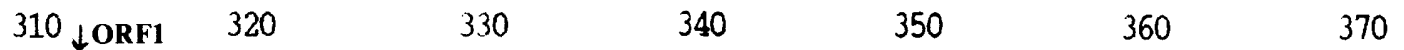

ATGAGAACAAC ATG AAG AAG AAG TCT CTG CTC CCC CTC GGC CTG GCC ATC GGT CTC GCC TCT CTC GCT GCC AGC CCT $\begin{array}{lllllllllllllllllllllll}M & K & K & K & S & L & L & P & L & G & L & A & I & G & L & A & S & L & A & A & S & P\end{array}$ $\begin{array}{lllllll}380 & 390 & 400 & 410 & 420 & 430 & 440\end{array}$

CTG ATC CAG GCC AGC ACC TAC ACC CAG ACC AAA TAC CCC ATC GIG CTG GCC CAC GGC ATG CTC GGC TTC GAC AAC

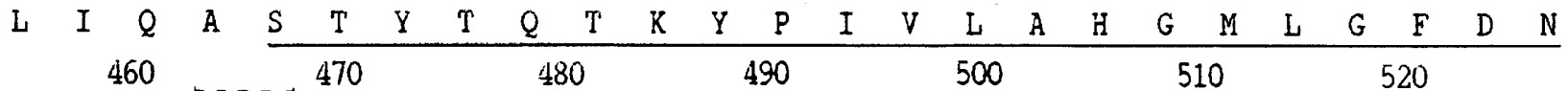
ATC CTC GGG GTC GAC TAC TGG TTC GGC ATT CCC AGC GCC TTG CGC CGT GAC GGT GCC CAG GTC TAC GTC ACC GAA

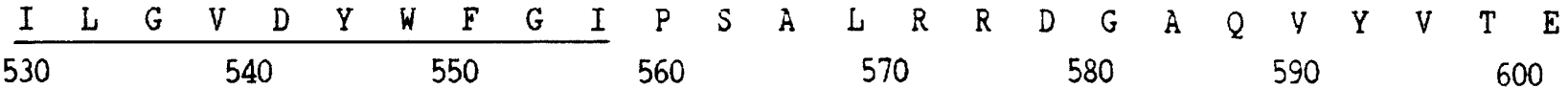
GTC AGC CAG TTG GAC ACC TCG GAA GTC CGC GGC GAG CAG TTG CTG CAA CAG GTG GAG GAA ATC GTC GCC CTC AGC $\begin{array}{llllllllllllllllllllllllll}V & S & Q & L & D & T & S & E & V & R & G & E & Q & L & L & Q & Q & V & E & E & I & V & A & L & S\end{array}$

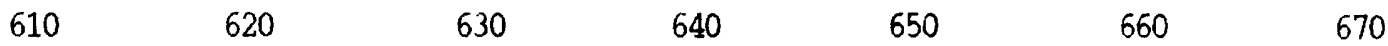

GGC CAG CCC AAG GTC AAC CTG ATC GGC CAC AGC CAC GGC GGG CCG ACC ATC CGC TAC GTC GCC GCC GTA CGT CCC $\begin{array}{lllllllllllllllllllllllll}G & Q & P & K & V & N & L & I & G & H & S & H & G & G & P & T & I & R & Y & V & A & A & V & R & P\end{array}$ $680 \quad 690 \quad 700 \quad 710 \quad 720 \quad 730 \quad 740 \quad 750$ GAC CTG ATC GCT TCC GCC ACC AGC GTC GGC GCC CCG CAC AAG GGT TCG GAC ACC GCC GAC TTC CTG CGC CAG ATC $\begin{array}{llllllllllllllllllllllllll}\mathrm{D} & \mathrm{L} & \mathrm{I} & \mathrm{A} & \mathrm{S} & \mathrm{A} & \mathrm{T} & \mathrm{S} & \mathrm{V} & \mathrm{G} & \mathrm{A} & \mathrm{P} & \mathrm{H} & \mathrm{K} & \mathrm{G} & \mathrm{S} & \mathrm{D} & \mathrm{T} & \mathrm{A} & \mathrm{D} & \mathrm{F} & \mathrm{L} & \mathrm{R} & \mathrm{Q} & \mathrm{I}\end{array}$

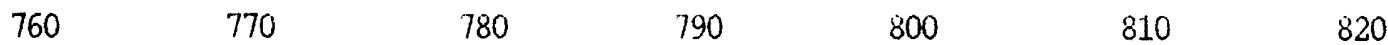

CCA CCG GGT TCG GCC GGC GAG GCA GTC CTC TCC GGG CTG GTC AAC AGC CTC GGC GCG CTG ATC AGC TTC CTT TCC $\begin{array}{llllllllllllllllllllllllll}P & P & G & S & A & G & E & A & V & L & S & G & L & V & N & S & L & G & A & L & I & S & F & L & S\end{array}$ $\begin{array}{llllllll}830 & 840 & 850 & 860 & 870 & 880 & 890 & 900\end{array}$ AGC GGC AGC ACC GGT ACG CAG AAT TCA CTG GGC TCG CTG GAG TCG CTG AAC AGC GAG GGT GCC GCG CGC TTC AAC $\begin{array}{lllllllllllllllllllllllll}S & G & S & T & G & T & Q & N & S & L & G & S & L & E & S & L & N & S & E & G & A & A & R & F & N\end{array}$ $\begin{array}{llllll}910 & 920 & 930 & 940 & 950 & 960\end{array}$

GCC AAG TAC CCG CAG GGC ATC CCC ACC TCG GCC TGC GGC GAA GGC GCC TAC AAG GTC AAC GGC GTG AGC TAT TAC $\begin{array}{lllllllllllllllllllllllll}A & K & Y & P & Q & G & I & P & T & S & A & C & G & E & G & A & Y & K & V & N & G & V & S & Y & Y\end{array}$ $\begin{array}{rrrrrrr}980 & 990 & 1000 & 1010 & 1020 & 1030 & 1040\end{array}$ TCC TGG AGC GGT TCC TCG CCG CTG ACC AAC TTC CTC GAT CCG AGC GAC GCC TTC CTC GGC GCC TCG TCG CTG ACC $\begin{array}{lllllllllllllllllllllllll}S & W & S & G & S & S & P & L & T & N & F & L & D & P & S & D & A & F & L & G & A & S & S & L & T\end{array}$ $\begin{array}{llllllll}1060 & 1070 & 1080 & 1090 & 1100 & 1110 & 1120 & 1\end{array}$

TTC AAG AAC GGC ACC GCC AAC GAC GCC CTG GTC GGC ACC TGC AGT TCG CAC CTG GGC ATG GTG ATC CGC GAC AAC $\begin{array}{llllllllllllllllllllllllll}F & K & N & G & T & A & N & D & G & L & V & G & T & C & S & S & H & L & G & M & V & I & R & D & N\end{array}$

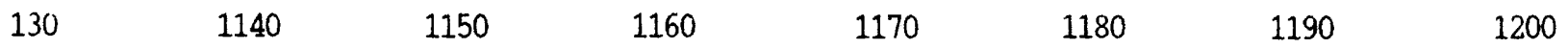
TAC LGG ATG AAC CAC CTG GAC GAG GTG AAC CAG GTC TTC GGC CTC ACC AGC CTG TTC GAG ACC AGC CCG GTC AGC $\begin{array}{llllllllllllllllllllllllll}\mathrm{Y} & \mathrm{R} & \mathrm{M} & \mathrm{N} & \mathrm{H} & \mathrm{L} & \mathrm{D} & \mathrm{E} & \mathrm{V} & \mathrm{N} & \mathrm{O} & \mathrm{V} & \mathrm{F} & \mathrm{G} & \mathrm{L} & \mathrm{T} & \mathrm{S} & \mathrm{L} & \mathrm{F} & \mathrm{E} & \mathrm{T} & \mathrm{S} & \mathrm{P} & \mathrm{V} & \mathrm{S}\end{array}$

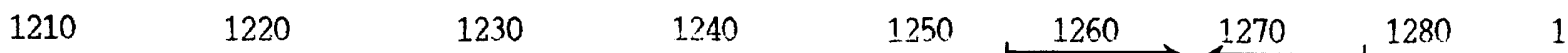
GTC TAC CGC CAG CAC GCC AAC CGC CTG AAG AAC GCC AGC CTG TAG GACCCCGGCCGGGGCCTCGGCCCCGGCCCTTTCCCGGAAG $\begin{array}{lllllllllllllllll}V & Y & R & Q & H & A & N & R & L & K & N & A & S & L & *\end{array}$

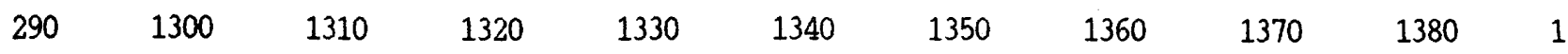
CCCCCTCGCGTGAAGAAAATCCTCCTGCTGATTCCACTGGCGTTCGCCGCCAGCCTGGCCTGGTTCGTCTGGCTGGAACCTTCCCCCGCACCCGAGACGG

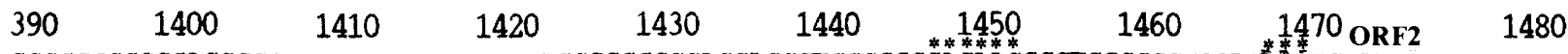
CGCCCCCGGCCAGCCCGCAGGCGGGCGCAGTCCACGCCCCGCCAGCAGCCTCCGCGGAGAAGCGGTGCCGGCCCTCAGGTC ATG CCG GCC AAG 


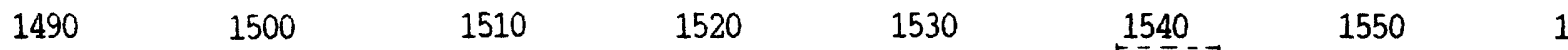

GTC GCG CCG CTG CCA ACC TCC TTC AGG GGC ACC AGC GTC GAT GGC AGT TTC AGT GTC GAC GCC AGC GGC AAC CTG

$\begin{array}{llllllllllllllllllllllllll}V & A & P & L & P & T & S & F & R & G & T & S & V & D & G & S & F & S & V & D & A & S & G & N & L\end{array}$

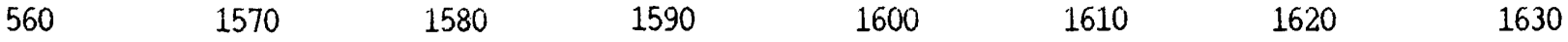

CTG ATC ACC CGC GAC ATC CGC AAC CTG TTC GAC TAC TTC CTC AGC GCC GTC GGC GAA GAG CCC CTG CAG CAA AGC

$\begin{array}{lllllllllllllllllllllllll}L & I & T & R & D & I & R & N & L & F & D & Y & F & L & S & A & V & G & E & E & P & L & Q & Q & S\end{array}$

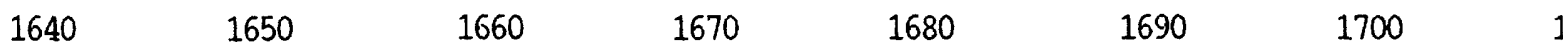

CTG GAC CGC CTG CGC GCC TAC ATC GCC GCC GAA CTC CAG GAG CCG GCG CGC GGC CAG GCG TTG GCG CTG ATG CAG

$\begin{array}{lllllllllllllllllllllllllll}L & D & R & L & R & A & Y & I & A & A & E & L & Q & E & P & A & R & G & Q & A & L & A & L & M & Q\end{array}$

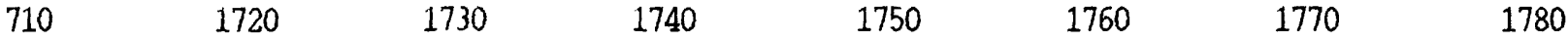

CAA TAC ATC GAC TAC AAG AAG GAA CTG GTG CTG CTC GAA CGC GAC CTG CCG CGC CTG GCC GAC CTC GAC GCC CTG $\begin{array}{llllllllllllllllllllllllll}Q & Y & I & D & Y & K & K & E & L & V & L & L & E & R & D & L & P & R & L & A & D & L & D & A & L\end{array}$

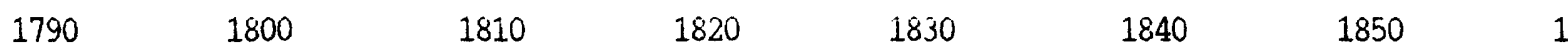

CGC CAG CGG GAA GCC GCG GTG AAA GCC CTG CGC GCG CGG ATC TTC AGC AAC GAA GCG CAC GTG GCG TTC TTC GCC

$\begin{array}{llllllllllllllllllllllllllll}R & Q & R & E & A & A & V & K & A & L & R & A & R & I & F & S & N & E & A & H & V & A & F & F & A\end{array}$

$\begin{array}{lllllll}860 & 1870 & 1880 & 1890 & 1900 & 1910 & 1920\end{array}$

GAC GAG GAA ACC TAC AAC CAG TTC ACC CTG GAG CGC CTG GCG ATC CGC CAG GAC GGC AAG CTC AGC GCC GAG GAA

$\begin{array}{lllllllllllllllllllllllll}D & E & E & T & Y & N & Q & F & T & L & E & R & L & A & I & R & Q & D & G & K & L & S & A & E & E\end{array}$

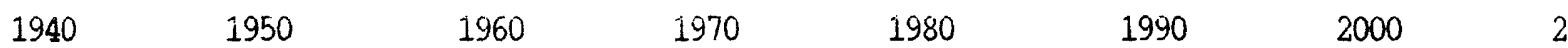

AAG GCC GCC GCC ATC GAC CGC CTG CGC GCC AGC CTG CCG GAA GAC CAG CAG GAA AGC GTG CTG CCG CAA CTG CAA

$\begin{array}{lllllllllllllllllllllllll}K & A & A & A & I & D & R & L & R & A & S & L & P & E & D & Q & Q & E & S & V & L & P & Q & L & Q\end{array}$

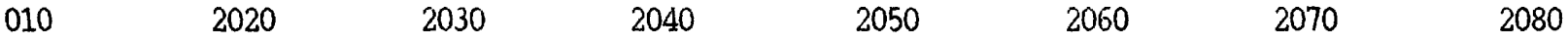

AGC GAA CTG CAG CAG CAG ACC GCC GCC CTC CAG GCC GCT GGC GCC GGC CCG GAA GCC ATC CGC CAG ATG CGT CAG

$\begin{array}{lllllllllllllllllllllllll}S & E & L & Q & Q & Q & T & A & A & L & \varrho & A & A & G & A & G & P & E & A & I & R & Q & M & R & Q\end{array}$

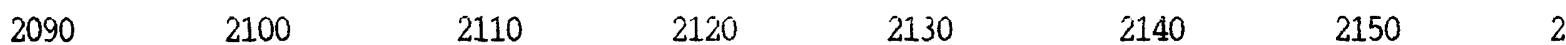

CAA CTG GTG GGC GCC GAA GCC ACC ACC CGC CTG GAG CAA CTC GAT CGG CAA CGC TCG GCC TGG AAG GGC CGG CTG

$\begin{array}{llllllllllllllllllllllllll}Q & L & V & G & A & E & A & T & T & R & L & E & Q & L & D & R & Q & R & S & A & W & K & G & R & L\end{array}$

$\begin{array}{lllllll}160 & 2170 & 2180 & 2190 & 2200 & 2210 & 2220\end{array}$

GAC GAC TAT TTC GCC GAG AAG AGC CGG ATC GAA GGC AAT ACC GGG GCT GAG CGA AGC CGA CCG CCG CGC GGC GGT

$\begin{array}{lllllllllllllllllllllllll}D & D & Y & F & A & E & K & S & R & I & E & G & N & T & G & A & E & R & S & R & P & P & R & G & G\end{array}$ $2240 \quad 2250 \quad 2260 \quad 2270 \quad 2280 \quad 2300 \quad 290 \quad 2$

CGA AAC GCC TGG CCG AGG AGC GCT TCA GCG AAC AGG AAC GCT TGC GCC TGG GCG CGC TGG GAA CAG ATG CGC CAG

$\begin{array}{lllllllllllllllllllllllll}R & N & A & W & P & R & S & A & S & A & N & R & N & A & C & A & W & A & R & W & E & Q & M & R & Q\end{array}$

$310 \quad 2320 \quad 2330 \quad 2340 \quad 2350$

GCC GAG CAG CGC TGA CCGGCACGGAAACGCCGAGAACGCGGCG

A $E \quad Q \quad R \quad$ *

Fig. 2. Nucleotide sequence and deduced amino acid sequence of the lipase (ORF1, lipA; nucleotide positions 312-1247) and of an unknown protein (ORF2, lipH; nucleotide positions 1471-2322). Nucleotide sequence (upper line): $\downarrow$, start of pSW118; *, ribosomebinding sites; $\rightarrow$, inverted repeats (termination); --, restriction site for Sall. amino acid sequence (lower line, single-letter code): - , $\mathrm{N}$-terminal amino acid sequence of the exported, mature lipase (Jaeger et al., 1992); =, active centre of lipase.

verified by sequence analysis of the $3^{\prime}$ part of the construct and by the fact that lipase was expressed in $E$. coli.

\section{Sequencing of lipA and properties of the lipase}

A total of $2893 \mathrm{bp}$ was sequenced in both directions, $2350 \mathrm{bp}$ of which are shown in Fig. 2. This sequence covers the $0.5,1.0$ and $1.3 \mathrm{~kb}$ Sall fragments, and contains two open reading frames, ORF1 and ORF2. The G/C content of this DNA is $67 \%$. Codons ending with $\mathrm{G}$ or $\mathrm{C}$ are strongly preferred: $90 \%$ for ORF1 and $86 \%$ for ORF 2 . Both characteristics are typical for DNA of $P$. aeruginosa (West \& Iglewski, 1988).

It was deduced that ORF1 is the lipase structural gene lipA. The open reading frame consists of $936 \mathrm{bp}$ coding 
Table 1. Comparison of the amino acid sequence of the lipase from P. aeruginosa PAOI with those of other Gram-negative bacteria

Maximum homology analysis was done by applying PROSIS, considering identical and conserved amino acids as follows: $\mathrm{A} / \mathrm{S} / \mathrm{T} / \mathrm{P} / \mathrm{G} ; \mathrm{N} / \mathrm{D} / \mathrm{E} / \mathrm{Q} ; \mathrm{M} / \mathrm{L} / \mathrm{I} / \mathrm{V} ; \mathrm{F} / \mathrm{Y} / \mathrm{W}$.

\begin{tabular}{|c|c|c|c|c|c|c|}
\hline \multirow{2}{*}{$\frac{\text { Strain compared }}{\text { Moraxella TA144 (lip } 3)}$} & \multicolumn{2}{|l|}{$\begin{array}{c}\text { Maximum } \\
\text { homology }(\%)\end{array}$} & \multicolumn{4}{|c|}{$\begin{array}{c}\text { Amino acid } \\
\text { sequences of } \\
\text { active centres }\end{array}$} \\
\hline & 50 & $\mathrm{C}$ & G & N S & $\mathrm{M} \mathrm{G}$ & $\mathrm{G}$ \\
\hline Moraxella TA144 (lip1) & 51 & I & G & W S & M G & G \\
\hline P. cepacia & 63 & V & G & H S & Q G & J G \\
\hline P. glumae & 63 & I & $\mathbf{G}$ & H S & Q $\mathrm{G}$ & G $\mathrm{G}$ \\
\hline Pseudomonas sp. M-12-33 & 63 & V & G & H S & $\mathrm{Q} \mathrm{G}$ & J $\mathrm{G}$ \\
\hline P. fragi IFO-12049 & 64 & I & G & H S & $\mathbf{Q} \mathrm{G}$ & $3 \mathrm{~A}$ \\
\hline P. fragi IFO-3458 & 67 & I & G & H S & Q G & G A \\
\hline Pseudomonas sp.* & 89 & $\mathbf{V}$ & G & H S & H G & $\mathbf{G} \mathrm{G}$ \\
\hline Pseudomonas sp. $\dagger$ & 99 & I & G & $\mathbf{H ~ S}$ & H G & $3 \mathrm{G}$ \\
\hline \multirow[t]{2}{*}{ Pseudomonas nov. sp. 109} & 100 & I & G & H S & $\mathrm{H} \mathrm{G}$ & $\mathrm{GC}$ \\
\hline & consensus: & - & G & $-\mathbf{S}$ & $-\mathrm{G}$ & G - \\
\hline
\end{tabular}

* Cox et al., 1991.

† Nishioka et al., 1991.

Table 2. Differences in the amino acid composition of lipases produced by three independently isolated pseudomonads

Apart from the $\mathbf{Q}$ to $\mathbf{H}$ change all changes are equivalent.

\begin{tabular}{|c|c|c|c|}
\hline $\begin{array}{l}\text { Residue } \\
\text { position }\end{array}$ & $\begin{array}{l}\text { P. aeruginosa } \\
\text { PAO1 }\end{array}$ & Pseudomonas sp.* & $\begin{array}{c}\text { Pseudomonas nov. sp. } \\
109 \dagger\end{array}$ \\
\hline 156 & V & $\cdots \cdots>I$ & \\
\hline 202 & $Q$ & $---->\quad H$ & \\
\hline 204 & I & $\ldots \cdots>\quad V$ & \\
\hline 125 & I & - > & $\mathbf{M}$ \\
\hline 126 & A & - & $\mathbf{P}$ \\
\hline 176 & $\mathrm{~T}$ & $->>$ & $\mathbf{A}$ \\
\hline
\end{tabular}

for a protein of 311 amino acids with $M_{\mathrm{r}}=32721$. Amino acid sequence analysis of the $\mathrm{N}$-terminus of the purified lipase of $P$. aeruginosa PAC1R revealed the sequence of the exported, mature protein (Jaeger et al., 1992). This sequence is identical to the deduced amino acid sequence of the $P$. aeruginosa PAO1 lipase, starting STYTQTKY ... (underlined in Fig. 2). The sequence of the $\mathrm{N}$-terminal 26 residues of the primary translation product is typical of leader sequences of secreted proteins (Watson, 1984). The mature protein deduced from the nucleotide sequence has a $M_{\mathrm{r}}$ of 30134 . The isoelectric point was calculated, according to Sillero \& Ribeiro (1989), to be 5.6. The polypeptide encoded by ORF1 includes an amino acid sequence known to be conserved in the active centre of lipases: I-G-H-S-H-G-G (Table 1 ). The overall amino acid composition corresponds well to that of known lipases, showing a high glycine
$(10.8 \mathrm{~mol} \%)$, leucine $(10.4 \mathrm{~mol} \%)$ and serine $(12.1 \mathrm{~mol} \%)$ content. The amino acid sequence of the gene product was aligned with lipases from pseudomonads and Moraxella. High levels of homology were revealed especially to lipases from pseudomonads ( $>60 \%$ ). There were only three variant residues when the sequence was aligned with lipases of Pseudomonas sp. (Nishioka et al., 1991) and Pseudomonas nov. sp. 109 (Ihara et al., 1991) (Table 2).

Hydropathy plots (Kyte \& Doolittle, 1982) indicated several hydrophobic domains, the most striking of which are located between residues $33-57$ and $152-171$. The predicted active centre (residues 105-111) is embedded in a hydrophilic domain. A lipoprotein consensus sequence (LVGTCSS) exists at an unusual position near the C-terminus of the protein (residues 257-263).

A putative Shine-Dalgarno sequence (GAGA) was identified 9 bp $5^{\prime}$ to the ATG start codon of ORF1. No promoter sequence for genes of pseudomonads (Deretic et al. 1987) or E. coli could be found. Regulatory sequences corresponding to $c r p$, lex $A$, fur, and $f n r$ boxes were checked for upstream of the ORF1 start codon, but were not found.

Downstream of the TAG stop codon there are inverted repeats that can form hairpin structures in RNA for rhoindependent termination of transcription.

ORF2 starts $220 \mathrm{bp}$ downstream from ORF1 (Fig. 2). ORF2 (lipH) codes for a protein of 283 amino acids with an $M_{\mathrm{r}}$ of 33587 . Hydropathy plots (Kyte \& Doolittle, 1982) suggest it to be a soluble, cytoplasmic protein; it has extensive hydrophilic domains, especially at the $\mathrm{C}$-terminus, and no signal sequence at the $\mathrm{N}$-terminus. Homology of approximately $40 \%$ to LimA of $P$. cepacia was found, with greater similarity in the $C$-terminal part of the protein (Fig. 3). LimA is coded by a sequence located directly downstream of the structural gene for the lipase of $P$. cepacia and is probably involved in the formation of an active extracellular enzyme (Jorgensen $e t$ al., 1991; Nakanishi et al., 1989).

\section{Expression of the lipase}

Plasmid pSW118 was transformed into E. coli JM109. Lipase activity was detectable only after induction with $1 \mathrm{mM}$-IPTG. Transcription of the gene was therefore under control of the lac promoter of pBluescript. After incubation at $37^{\circ} \mathrm{C}$ for $16 \mathrm{~h}$, no detectable lipase activity was found in cell-free culture medium. After disintegration of the cells by sonication, a lipase activity of $2.5 \mathrm{nmol} \mathrm{min}{ }^{-1} \mathrm{ml}^{-1}$ per $10^{8}$ cells was measured (data corrected for esterase activity of $E$. coli).

Expression of the lipase gene in lipase-defective mutants 6-1 and 29-1 of $P$. aeruginosa PAOl was tested using calcium triolein agar plates (Table 3 ). The broad- 


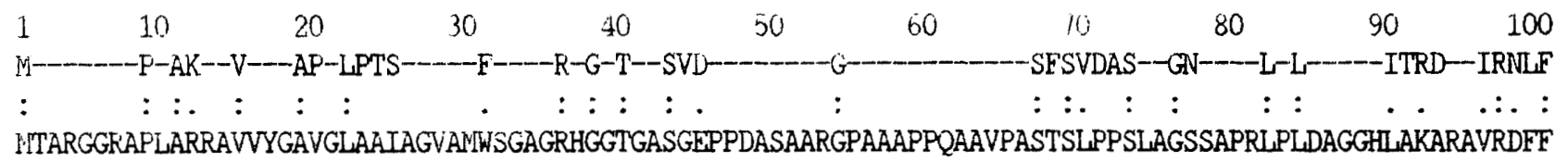

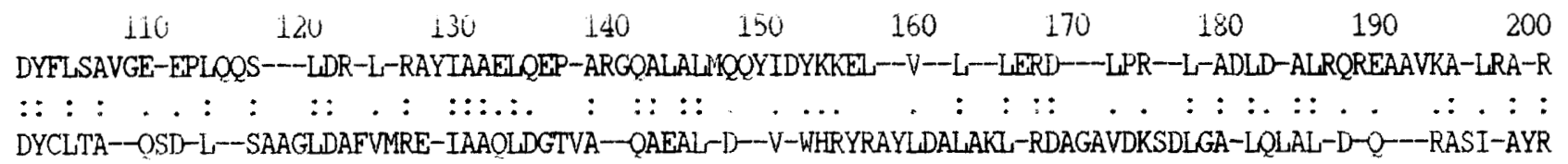

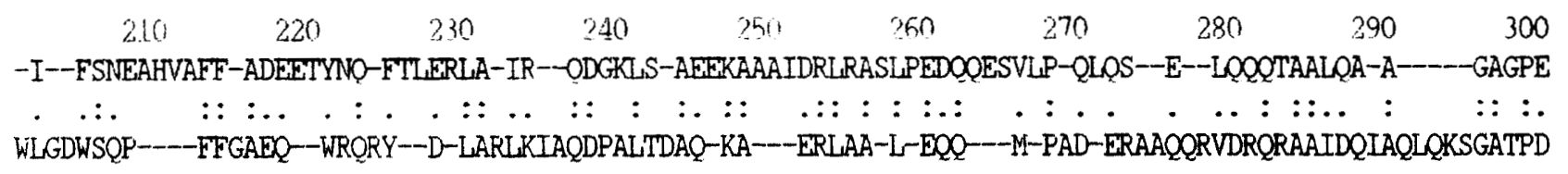

$\begin{array}{lllllllll}310 & 320 & 330 & 340 & 350 & 360 & 370 & 380 & 390\end{array}$ AIR-QMRQQLVGAEATTRLEDLDRQRSA-W-KGRLDYFAEKSRIEGNTGAERSRPPRGGRNAWPRSASANRNAC-AWARWEQMRQAEOR : : : : : : : : : :... : : : : : : : : : : : : . . ..: : : .:: $:$ AMRAQLTQTL-GPEAAARVAQMQQDD-ASWQR-KYADYAAQRAQIESA-GL--S-P- - Q-

\section{0 \\ AASLDRGAGSAR}

Fig. 3. Alignment of the amino acid sequences deduced from lipH of P. aeruginosa PAO1 and limA of $P$. cepacia (Jorgensen et al., 1991). Upper line, LipH; lower line, LimA. Analysis was done with PROSIS. Symbols :, identical amino acids; $\odot$, conserved amino acids $(A / S / T / P / G ; N / D / E / Q ; M / L / I / V ; F / Y / W)$.

host-range plasmid pSW118Ps carried the lipase gene (lipA) only, while plasmid pSW121Ps contained both ORF1 (lipA) and ORF2 (lipH) (Fig. 1). The lipase deficiency of mutant 29-1 could be complemented by introducing $\operatorname{lip} A$ alone, but expression of active extracellular lipase in mutant 6-1 was successful only in the presence of lipH (Kaudelka et al., 1992).

\section{Conservation of the lipase gene in pseudomonads}

The two SalI fragments of pSW101, including lipH and most of lipA of P. aeruginosa PAO1, were used as probes to study homology with lipase genes in other species of Pseudomonas. Under stringent conditions, all 10 strains of $P$. aeruginosa tested gave positive signals (Fig. 4). The $S a l$ restriction pattern has been mostly conserved, with the exception of the two $P$. aeruginosa strains $\mathrm{CF}_{2} / \mathrm{M}_{1}$ and Habs 12. They showed only a single band at about $2.2 \mathrm{~kb}$. As this molecular mass equals the sum of the single fragments, no SalI restriction site can be present within ORF2.

It is possible to distinguish between strains of $P$. aeruginosa and other lipase-producing pseudomonads by using this probe. $P$. cepacia DSM 50181, $P$. putida and $P$. fluorescens AFT 36 did not hybridize under either stringent or relaxed conditions. The latter
Table 3. Complementation of lip mutants 6-1 and 29-1 of $P$. aeruginosa $P A O 1$ with lipA and lipH

Mutant strains were transformed with plasmid DNA. Lipase activity was detected on triolein plates after overnight incubation at $37^{\circ} \mathrm{C}$.

\begin{tabular}{lccc}
\hline & & \multicolumn{2}{c}{ Complementation of } \\
\cline { 3 - 4 } Plasmid & Gene(s) & $6-1$ & $29-1$ \\
\hline pSW118Ps & lipA & - & + \\
pSW121Ps & lipA + lipH & + & + \\
pUC19Ps & - & - & - \\
\hline
\end{tabular}

experiments were performed with ${ }^{32} \mathrm{P}$-radioactive as well as with digoxigenin-labelled probes. $P$. maltophilia DSM 50170 and $P$. stutzeri AS 70 gave weak but indistinct hybridization signals only under relaxed conditions. $P$. alcaligenes DSM 50342 was the only strain that showed a faint band under stringent conditions.

Based on these findings, we cloned the lipase gene of $P$. alcaligenes DSM 50342 on a $4.7 \mathrm{~kb}$ Sall restriction fragment ligated into pUC19 (pCH1). 


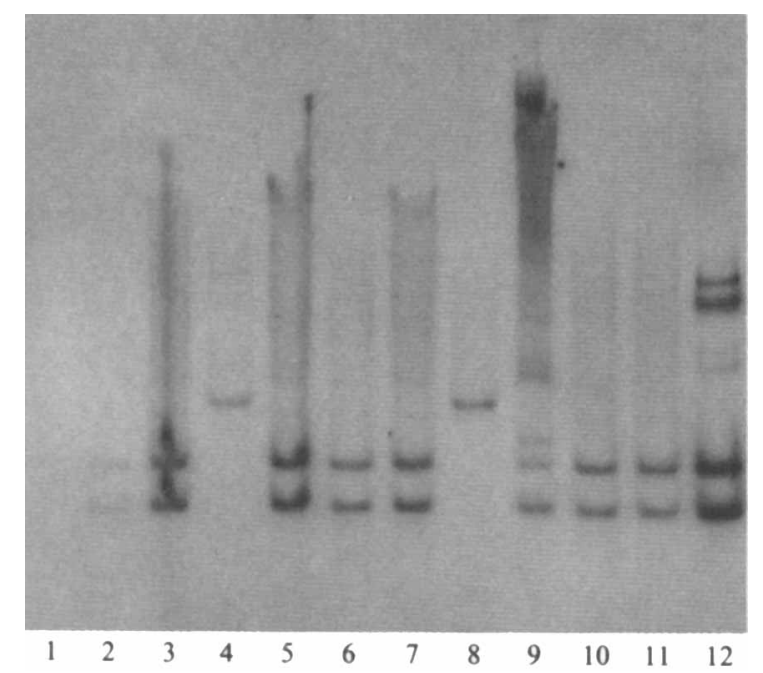

Fig. 4. Southern blot analysis of different strains of $P$. aeruginosa. Chromosomal DNA $(10 \mu \mathrm{g})$ from each strain $(1 \mu \mathrm{g}$ DNA from $P$. aeruginosa $\mathrm{PAO}$ ) was digested with $30 \mathrm{U}$ restriction enzyme Sall. Southern hybridization was performed at $60^{\circ} \mathrm{C}$ using ${ }^{32} \mathrm{P}$-labelled double $S a$ II insert from plasmid pSW101 $(1.0-1.3 \mathrm{~kb})$. The insert codes for $85 \%$ of the lipase gene (ORF1, lipA) and for the complete ORF2 (lipH). Lanes: 1, E. coli K12 (negative control); 2, P. aeruginosa PAO1; 3, $P$. aeruginosa $\mathrm{CF}_{1} / \mathrm{M}_{1} ; 4, P$. aeruginosa $\mathrm{CF}_{2} / \mathrm{M}_{1} ; 5, P$. aeruginosa $\mathrm{CF}_{3} / \mathrm{M}_{1} ; 6, P$. aeruginosa DE-27; $7, P$. aeruginosa Habs $2 ; 8, P$. aeruginosa Habs $12 ; 9, P$. aeruginosa ATCC $9027 ; 10, P$. aeruginosa ATCC 27853; 11, P. aeruginosa FRD2; 12, pSW101 (positive control).

\section{Discussion}

\section{Analysis of the lipase gene (lipA) and gene product (LipA)}

The structural gene of the extracellular lipase (lipA) of $P$. aeruginosa PAOl has been cloned, sequenced and expressed in both homologous and heterologous hosts.

Biochemical studies of purified lipase proteins of $P$. aeruginosa PAC1R (Stuer et al., 1986; Jaeger et al., 1991, 1992) and of $P$. aeruginosa EF2 (Gilbert et al., 1991) yielded results which correspond very well to data deduced from the nucleotide sequence of the lipase gene of $P$. aeruginosa PAO1. These data comprise the molecular mass of the enzyme, the isoelectric point (calculated: $\mathrm{pI}=5.6$; analysed by isoelectric focussing: pI $=5 \cdot 8$ ), the overall amino acid composition and the amino acid sequence of the $\mathrm{N}$-terminus of the secreted protein. The only exception was the high glycine content of the hydrolysate of the lipase.

The enzyme is probably synthesized as a propeptide of 311 residues, with a 26 residue leader peptide that is cleaved off during transport of the lipase across the cytoplasmic membrane. The signal sequence is composed of three positively charged amino acids at the Nterminus (KKK) followed by a stretch of hydrophobic amino acids. Besides this characteristic motif of a leader sequence, the amino acid sequence of the mature extracellular protein starts with STY.. (Fig. 2) just downstream of the putative signal protease cleavage site between A and S. SDS-PAGE of the purified extracellular lipase (Stuer et al., 1986; Gilbert et al., 1991) revealed an active extracellular enzyme of $M_{\mathrm{r}} 29000$, corresponding well to the $M_{\mathrm{r}}$ of 30134 predicted for the mature protein from the nucleotide sequence. The entire lipase gene codes for a proenzyme of $M_{\mathrm{r}} 32721$. Though no active lipase is found intracellularly (Stuer et al., 1986), Koch and Jaeger immunologically detected an inactive protein of $M_{\mathrm{r}} 32000$ (personal communication). These findings suggest that the extracellular lipase of $P$. aeruginosa $\mathrm{PAO} 1$ is produced as an inactive proenzyme with a leader peptide cleaved off during transport. Sequence data from other Gram-negative bacteria also reveal that these extracellular lipases are synthesized as proenzymes. In Gram-positive bacteria, extracellular lipases have to undergo a more complicated conversion involving a pre-proenzyme (Götz, 1991).

A special feature of the lipase protein of $P$. aeruginosa PAO1 is a stretch of 27 highly hydrophobic amino acids between residues 33 and 59 of the proenzyme at the $\mathrm{N}$ terminus of the mature protein. This resembles a second leader sequence that is not cleaved off during export of the protein. This domain might be responsible for hydrophobic interactions between the enzyme and the lipopolysaccharides (LPS) released from the outer membrane. This hypothesis is based on findings of Stuer et al. (1986). They showed that the extracellular lipase of $P$. aeruginosa PAC1R is associated with LPS in cell-free growth medium and that the presence of LPS positively influences enzyme activity. As the lipase is an enzyme that mainly catalyses reactions at the water-lipid interphase it should have some hydrophobic domains for binding to such interphases. One such domain is found between residues 152 and 171 .

A conserved sequence (IGHSHGG; Fig. 2) typical for many lipases and thought to be involved in lipolysis was found. No conclusions about amino acids belonging to the three-dimensional His-Ser-Gln/Asp triad can be drawn from primary structure alone.

\section{Analysis of ORF2 (lipH) involved in expression of lipA}

Sequence analysis revealed a second open reading frame (ORF2; lipH) downstream from lipA. It appears to encode a soluble cytoplasmic protein, in that it lacks a typical leader sequence. The function of $\mathrm{LipH}$ is yet unknown, but seems to be connected to lipase expression in $P$. aeruginosa PAO1. In complementation experiments (Table 3) we deduced that $l i p H$ codes for a protein that is required for the formation of an active extracellular 
lipase. lip mutant 6-1, formally considered to be defective in lipA (Wohlfarth \& Winkler, 1988) did not show lipase activity, either extracellularly or intracellularly. This mutant cannot be complemented by lip $A$. Recent sequencing results (Kaudelka et al., 1992) indicated that mutant 6-1 is defective in lipH rather than in lipA. The gene product of lipH showed limited homology $(40 \%)$ to $\operatorname{LimA}$, a protein that is presumed to be involved in lipase export in $P$. cepacia (Jorgensen et al., 1991). Protein sequence comparisons did not show any similarity between LipH and XcpA (Bally et al., 1991), XcpY or XcpZ (Filloux et al., 1990), which are involved in protein export in $P$. aeruginosa. No motif common to activator proteins (e.g. LasR of two-component systems; Gambello \& Iglewski, 1991) could be identified. We suggest that there is at least one other gene (lipH) specifically involved in the formation of an active extracellular lipase.

Expression of lipA in E. coli under control of the lac promoter is very low even after induction of enzyme synthesis by IPTG. Experiments should be done to verify whether the presence of lipH improves lipase expression in E. coli.

Active lipase is produced in very small amounts, even in the natural host strain (Stuer et al., 1986). So far nothing is known about regulation of lipase expression and transport. Regulation by stress (SOS) or cAMP as was found for lipase expression in Serratia marcescens (Ball et al., 1990; Winkler et al., 1975) could not be confirmed for $P$. aeruginosa PAOl.

\section{Conservation of lipA amongst pseudomonads}

The structural genes for the lipases produced by various strains of $P$. aeruginosa showed a high degree of sequence homology by Southern hybridization analysis under stringent conditions. Moreover, Nishioka et al. (1991) and Ihara et al. (1991) published amino acid sequences deduced from lipase gene sequences of unidentified species of Pseudomonas. When comparing these sequences with that of the lipase studied here, it seemed very likely that both strains belong to the species $P$. aeruginosa. Both sequences differ by only three amino acids (Table 2). Actually, Pseudomonas sp. of Nishioka $e t$ al. (1991) was classified as $P$. aeruginosa TE3285 (Gilbert et al., 1991). This very close overall nucleotide and amino acid sequence homology of the lipases of the three strains P. aeruginosa PAO1, Pseudomonas sp. (Nishioka et al., 1991) and Pseudomonas nov. sp. 109 (Ihara et al., 1991) as well as the identical $\mathrm{N}$-termini of the mature lipase protein of $P$. aeruginosa PAC1R and EF2 (Jaeger et al., 1992; Gilbert et al., 1991) shows a considerable conservation of the lipase gene and gene-product amongst different strains of $\boldsymbol{P}$. aeruginosa.
Sequence homologies between lipase genes are much less when comparing genes from distantly related pseudomonads. Data given in Table 1 and Southern blot analysis (Fig. 4) support this statement. P. aeruginosa PAOl, P. alcaligenes DSM 50342 and Pseudomonas sp. (P. M. Andreoli, personal communication) belong to rRNA group 1, and are thus very closely related. Their lipases also showed a high degree of homology at the amino acid $(89 \%)$ as well as the nucleotide level. More distantly related strains showed lower homology at the amino acid level (63\% with $P$. cepacia) and less when comparing nucleotide sequences. In good agreement with these findings, Southern blot hybridizations under stringent conditions gave no positive signals. Vasil et al. (1986) obtained similar results when studying various strains of $P$. aeruginosa using the exotoxin A gene as a probe. Perhaps the lipase gene and lipase protein might be used to classify unknown species of Pseudomonas.

\section{Description of gene copy}

Palmeros et al. (1991) reported the cloning of a lipase gene from $P$. aeruginosa IGB83 that codes for a protein of $M_{\mathrm{r}} 54000$. The activity of this enzyme was tested with tributyrine, a substrate that can be hydrolysed by lipases as well as unspecific esterases. It has to be verified that this enzyme is really a new type of lipase and is not a membrane-bound esterase $\left(M_{\mathrm{r}} 55000\right.$; Ohkawa et al., 1979). Our Southern blot studies clearly showed that only a single copy of a lipase gene is present in the chromosome of $P$. aeruginosa PAO1 (data not shown). In Moraxella sp. TA144, however, Feller et al. (1991) discovered two different lipase genes (lipl; lip3) coding for proteins of nearly identical $M_{\mathrm{r}}(\mathrm{LipA}, 34662 ; \mathrm{LipB}$, 34772).

We thank Drs S. Chen, B. Holloway, D. Ohman, and K. Timmis for kindly supplying us with bacterial strains and plasmids. We also acknowledge $\mathbf{H}$. Kaudelka and $B$. Rehm who checked some parts of the nucleotide sequence. Part of this work was financially supported by Gist-Brocades, Delft (The Netherlands).

\section{References}

ANDREOLI, P. M., CoX, M. M. J., FARIN, F. \& WohlFaRTH, S. (1989) Molecular cloning and expression of genes encoding lipolytic enzymes. European Patent no. $0334462 \mathrm{Al}$

Aoyama, S., Yoshida, N. \& INOUYe, S. (1988). Cloning, sequencing and expression of the lipase gene from Pseudomonas fragi IFO-12049 in E. coli. FEBS Letters 242, 36-40.

Bagdasarian, M., LuRz, R., RÜCKert, B., Franklin, F. C. H., Bagdasarian, M. M., Frey, J. \& Timmis, K. N. (1981). Specificpurpose plasmid cloning vectors. II. Broad host range, high copy number, RSF1010-derived vectors, and a host-vector system for gene cloning in Pseudomonas. Gene 16, 237-247. 
Bally, M., Ball, G., Badere, A. \& Lazdunski, A. (1991). Protein secretion in Pseudomonas aeruginosa: The xcpA gene encodes an integral inner membrane protein homologous to Klebsiella pneumoniae secretion function protein PulO. Journal of Bacteriology 173, 479486.

Brady, L., Brzozowski, A. M., Derewenda, Z. S., Dodson, E., Dodson, G., Tolley, S., Turkenburg, J. P., Christiansen, L. Huge-Jensen, B., Norskov, L., Thim, L. \& Menge, U. (1990). A serine protease triad forms the catalytic centre of a triacylglycerol lipase. Nature, London 343, 767-770.

Chen, S. T., Jordan, E. M., Wilson, R. B., Draper, R. K. \& Clowes, R. C. (1987). Transcription and expression of the exotoxin A gene of Pseudomonas aeruginosa. Journal of General Microbiology 133, 30813091

Chung, G. H., Lee, Y. P., Yoo, O. J. \& Rhee, J. S. (1991). Overexpression of a thermostable lipase gene from Pseudomonas fluorescens in Escherichia coli. Applied Microbiology and Biotechnology 35, 237-241.

Cox, M. M. J., Andreoli, P. M., Gerritse, G. \& QuaX, W. J. (1991). Molecular cloning, characterization and expression of a lipase gene from Pseudomonas species. In: Book of Abstracts of Third International Symposium on Pseudomonad Biology and Biotechnology in Trieste, p. 153.

DEININGER, P. L. (1983). Random subcloning of sonicated DNA: Application to shotgun DNA sequence analysis. Analytical Biochemistry 129, 216-223.

Deretic, V., Gill, J. F. \& Chakrabarty, A. M. (1987). Pseudomonas aeruginosa infection in cystic fibrosis: nucleotide sequence and transcriptional regulation of the algD gene. Nucleic Acids Research $15,4567-4581$

Feller, G., ThIRY, M. \& Gerday, C. (1990). Sequence of a lipase gene from the antarctic psychrotroph Moraxella TA144. Nucleic Acids Research 18, 6431.

Feller, G., Thiry, M. \& Gerday, C. (1991). Nucleotide sequence of the lipase gene lip3 from the antarctic psychrotroph Moraxella TA144. Biochimica et Biophysica Acta 1088, 323-324.

Filloux, A., Bally, M., Ball, G., AKrim, M., Tommassen, J. \& LAZDUNSKI, A. (1990). Protein secretion in Gram-negative bacteria: transport across the outer membrane involves common mechanisms in different bacteria. EMBO Journal 13, 4323-4329.

Frenken, L. G. J., Bos, J. W., Visser, C. \& Verrips, C. T. (1991). Isolation and characterization of the Pseudomonas glumae lipase gene and a second gene essential for lipase secretion. In: Book of Abstracts of Third International Symposium on Pseudomonad Biology and Biotechnology in Trieste, p. 153.

GAMBELLO, M. J. \& IGLEWSKI, B. H. (1991). Cloning and characterization of the Pseudomonas aeruginosa las $R$ gene, transcriptional activator of elastase expression. Journal of Bacteriology 173, 30003009.

Gilbert, E. J., Cornish, A. \& Jones, C. W. (1991). Purification and properties of extracellular lipase from Pseudomonas aeruginosa EF2. Journal of General Microbiology 137, 2223-2229.

GöTZ, F. (1991). Staphylococcal lipases and phospholipases. In Lipases: Structure, Mechanism and Genetic Engineering (GBF monograph no. 16), pp. 285-292. Edited by L. Alberghina, R. D. Schmid \& R. Verger. Weinheim: VCH.

GöTZ, F., POPP, F., KoRn, E. \& SCHLEIFER, K. H. (1985). Complete nucleotide sequence of the lipase gene from Staphylococcus hyicus cloned in Staphylococcus carnosus. Nucleic Acids Research 13, 58955906.

Gray, G. L., SMITH, D. H., BaldRIDGe, J. S., Harkins, H. N., Vasil, M. L., CHEN, E. Y. \& HeYNeKeR, H. L. (1984). Cloning, nucleotide sequence, and expression in Escherichia coli of the exotoxin A structural gene of Pseudomonas aeruginosa. Proceedings of the National Academy of Sciences of the United States of America 81, 2645-2649.

HENIKOFF, S. (1984). Unidirectional digestion with exonuclease III creates targeted breakpoints for DNA sequencing. Gene 28, 351359.

holloway, B. W., Krishnapillai, V. \& Morgan, A. F. (1979). Chromosomal genetics of Pseudomonas. Microbiological Reviews 43, 73-102.
Ihara, F., Kageyama, Y., Hirata, M., Nihira, T. \& Yamada, Y. (1991). Purification, characterization, and molecular cloning of lactonizing lipase from Pseudomonas species. Journal of Biological Chemistry 266, 18135-18140.

JAEGER, K.-E., Wohlfarth, S. \& WINKLER, U. K. (1991). Extracellular lipase of Pseudomonas aeruginosa. In Lipases: Structure, Mechanism and Genetic Engineering (GBF monograph no. 16), pp. 381-384 Edited by L. Alberghina, R. D. Schmid \& R. Verger. Weinheim: $\mathrm{VCH}$.

JaEger, K.-E., AdRian, F.-J., Meyer, H. E., Hancock, R. E. W. \& WinkLer, U. K. (1992). Extracellular lipase from Pseudomonas aeruginosa is an amphiphilic protein. Biochima et Biophysica Acta, in the Press.

Jorgensen, S., Skov, K. W. \& Diderichsen, B. (1991). Cloning, sequence, and expression of a lipase gene from Pseudomonas cepacia Lipase production in heterologous hosts requires two Pseudomonas genes. Journal of Bacteriology 173, 559-567.

KaUdelKa, H., Wohlfarth, S. \& WinkLer, U. (1992). Molecular characterization of two lipase-defective mutants of Pseudomonas aeruginosa. BioEngineering 8 (Abstracts of Gemeinsame Frühjahrstagung der VAAM und DHGM), 79.

KugimiYa, W., Otani, Y., Hashimoto, Y. \& TaKagi, Y. (1986) Molecular cloning and nucleotide sequence of the lipase gene from Pseudomonas fragi. Biochemical and Biophysical Research Communications 141, 185-190.

KYTE, J. \& DoolitTle, R. F. (1982). A simple method for displaying the hydropathic character of a protein. Journal of Molecular Biology 157, 105-132.

LeE, C. Y. \& IANDolo, J. J. (1986). Lysogenic conversion of staphylococcal lipase is caused by insertion of the bacteriophage L54a genome into the lipase structural gene. Journal of Bacteriology 166, 385-391.

MARMUR, J. (1961). A procedure for the isolation of deoxyribonucleic acid from micro-organisms. Journal of Molecular Biology 3, 208-218.

NAKaNishi, Y., KURONo, Y., KoIDE, Y. \& BePPU, T. (1989). Recombinant DNA, bacterium of the genus pseudomonas containing it, and process for preparing lipase by using it. European Patent No. 0331376 A2.

Nakanishi, Y., Watanabe, H., Washizu, K., Narahashi, Y. \& KURONO, Y. (1991). Cloning, sequencing and regulation of the lipase gene from Pseudomonas sp. M-12-33. In Lipases: Structure, Mechanism and Genetic Engineering (GBF monograph no. 16), pp. 263 266. Edited by L. Alberghina, R. D. Schmid \& R. Verger Weinheim: $\mathrm{VCH}$.

Nishioka, T., Chihara-Shiomi, M., Yoshikawa, K., Inagaki, M. Yamamoto, Y., Hiratake, J., Baba, N. \& OdA, J. (1991). Lipase from Pseudomonas sp. : Reactions, cloning, and amino acid sequence analysis. In Lipases: Structure, Mechanism and Genetic Engineering (GBF monograph no. 16), pp. 253-262. Edited by L. Alberghina, R. D. Schmid \& R. Verger. Weinheim: VCH

OhKaWa, I., Shiga, S. \& Kageyama, M. (1979). An esterase on the outer membrane of Pseudomonas aeruginosa for the hydrolysis of long chain acyl esters. Journal of Biochemistry 86, 643-656.

O'HoY, K. \& KrishnapillaI, V. (1987). Recalibration of the Pseudomonas aeruginosa PAO chromosome map in time units using high-frequency-of-recombination donors. Genetics 115, 611-618.

Palmeros, B., Tamayo, E. M., Ramirez, G., Najera, R. \& SoberonChaves, G. (1991). Cloning and characterization of a Pseudomonas aeruginosa lipase. In: Book of Abstracts of Third International Symposium on Pseudomonad Biology and Biotechnology in Trieste, $\mathrm{p}$. 167.

Sambrook, J., Fritsch, E. F. \& Maniatis, T. (1989). Molecular Cloning: a Laboratory Manual, 2nd Edn. Cold Spring Harbor, NY: Cold Spring Harbor Laboratory.

SANGER, F., Nicklen, S. \& Coulson, A. R. (1977). DNA sequencing with chain terminating inhibitors. Proceedings of the National Academy of Sciences of the United States of America 74, 5463-5467.

SCHRAG, J. D., LI, Y., Wu, S. \& CYGleR, M. (1991). Ser-His-Glu triad forms the catalytic site of the lipase from Geotrichum candidum. Nature, London 351, 761-764.

Sillero, A. \& Ribeiro, J. M. (1989). Isoelectric points of proteins Theoretical determination. Analytical Biochemistry 179, 319-325. 
STADEN, R. (1980). A new computer method for the storage and manipulation of DNA gel reading data. Nucleic Acids Research 8 , 3673-3694.

Stuer, W., JAeger, K. E. \& Winkler, U. K. (1986). Purification of extracellular lipase from Pseudomonas aeruginosa. Journal of Bacteriology 168, 1070-1074.

Vasil, M. L., Chamberlain, C. \& Grant, C. C. R. (1986). Molecular studies of Pseudomonas exotoxin A gene. Infection and Immunity 52, 538-548.

WATSON, M. E. E. (1984). Compilation of published signal sequences. Nucleic Acids Research 13, 5145-5164.

WeSt, S. E. H. \& IGLEWSKI, B. H. (1988). Codon usage in Pseudomonas aeruginosa. Nucleic Acids Research 16, 9323-9335.
WiNkLeR, U., SCholle, H. \& Bohne, L. (1975). Mutants of Serratia marcescens lacking cyclic nucleotide phosphodiesterase activity and requiring cyclic $3^{\prime}, 5^{\prime}$-AMP for the utilization of various carbohydrates. Archives of Microbiology 104, 189-196.

WINKLER, F. K., D'ARCY, A. \& HUNZIKER, W. (1990). Structure of human pancreatic lipase. Nature, London 343, 771-774.

WOHLFARTH, S. \& WINKLER, U. K. (1988). Chromosomal mapping and cloning of the lipase gene of Pseudomonas aeruginosa. Journal of General Microbiology 134, 433-440.

YANISCh-PERRON, C., VieIRA, J. \& Messing, J. (1985). Improved M13 phage cloning vectors and host strains: nucleotide sequences of the M13mp18 and pUC19 vectors. Gene 33, 103-119. 